\title{
Effectiveness and effects of attempts to regulate the UK petrol industry.
}

This paper evaluates the impact that investigation and regulation of the UK petrol industry has had on the profitability of the companies. Using a gross margin for petrol, we estimate a series of variable parameter autoregressive processes. The results demonstrate that the 1979 Monopolies and Mergers Commission investigation into the industry, caused a long term decline in profit margins in the industry, despite the fact that no recommendations or undertakings were made. This cannot however be said for subsequent investigations.

Nigel Driffield \& Chris Ioannidis,

Cardiff Business School.

JEL Classification : L10, L51. 


\section{Introduction}

The petrol industry is one of the most investigated industries in the UK. It has experienced in the past twenty years, two Monopolies and Mergers Commission industry investigations, and two investigations by the House of Commons Trade and Industry Select Committee (1988a, 1988b). In all of the investigations since 1979, the various committees have found that while the industry is a 'complex monopoly', there is nothing evident in the industry's conduct that is against the public interest.

This paper will focus on the impact on the gross margin of main investigations into the industry, the two MMC enquires, $\operatorname{MMC}(1979,1990)$. These investigations have essentially been concerned with the oligopolistic nature of the petrol industry, and the possible anticompetitive effects. However, the only outcome of these has been for the Office of Fair Trading (OFT) to 'keep the industry under review'. This is despite the fact that the industry has many characteristics which are associated with anticompetitive conduct and monopoly rents. Indeed, the OFT have recently published a report into the supply of petrol, arguing that there is no case for a rereferral to the MMC. ${ }^{1}$

Section one is concerned with a description of why monopoly profits are possible in the petrol industry. Section two outlines the investigations that have been carried out into the potential for monopoly abuse, and section three focuses on the impact of the investigations on the profit margin. Section four outlines the procedures used in the analysis, while sections five and six present the results and conclusions. 


\section{Oligopoly in the UK petrol market}

The five firm concentration ratio was above $70 \%$ for the whole of the period 1973-1993, and as such, the likelihood of monopoly pricing in the industry is high. The MMC (1990) reports that there is very little variation in price across firms, and the market shares of the five leading companies have been very stable over time. Further, there is significant evidence of sticky pricing in petrol, Bacon (1992). Borenstein et al (1997) show that retail petrol prices in the US, respond faster to oil price increases than they do to oil price falls. They attribute this to asymmetry in the costs of inventory adjustment, but also possibly to the oligopolistic nature of the industry.

\subsection{Vertical Restraints in Petrol Supply}

The MMC determined in 1979 that the industry was a 'complex monopoly' in favour of the major firms, as a result of vertical restraints. The most obvious efficiency explanation for vertical restraints or vertical integration in the petrol industry is the 'double marginalisation' principle. The industry has however never used this argument, denying that upstream monopoly power exists. In submissions to the MMC (1990), the large petrol companies have employed the 'Chicago School' argument, see for example Bork (1978), or Posner (1981), to defend their position. One of the most powerful arguments in favour of permitting the vertical relations in the petrol industry, is put forward by Dobson \& Waterson (1996). They suggest that as there are no economies of scope in petrol retailing, the stance taken by the MMC, to view these arrangements as not against the public interest is a fair one. 
Vickers and Waterson (1991) discuss the general effects of vertical restraints, many of which are applicable to the petrol industry. Vertical restraints, are employed to remove inter-brand competition at the retail level, while the petrol companies ensure through their licensing of sites that there is little intra-brand competition. Slade (1993) demonstrates a similar result in a study of petrol retailing in Vancouver. While it would appear to be the case that oil companies gain from these arrangements, the extent to which the retailers gain, is a function of local market conditions.

\subsection{Price Discrimination}

The petrol companies utilise the system of Selective Price Support. Under these agreements, wholesalers provide retailers with discounted prices, in locations where they face significant inter-brand competition. Gupta et al (1994) show that under these conditions, spatial price discrimination will serve to increase monopoly profits, while Armstrong \& Vickers (1993) show that, when used to protect certain markets, such price discrimination can form a significant barrier to entry.

\subsection{Empirical evidence of Pricing and Oligopolistic Interaction in the petrol Industry}

Much of the work carried out in this area focuses on petrol pricing within an oligopolistic market in North America, see for example, Slade $(1990,1992,1993)$ and Borenstein \& Shepard (1996). Borenstein \& Shepard (1996) for example, report significant evidence of tacit collusion between petrol retailers, based on a standard model of petrol prices. However, due to the extensive vertical links in the UK industry, it is necessary to focus the analysis on the conduct of petrol companies, and as such interpretation of more aggregate margins is necessary. 


\section{Investigation into the UK petrol industry}

\subsection{Monopolies and Mergers Commission Investigation}

The main mechanism for the implementation of UK competition policy, has been based on the 1978 Fair Trade Act, which replaced the 1948 FTA. Under this act, the OFT referred any industry for investigation by the MMC, if it suspected conduct which may be against the public interest. ${ }^{2}$ The 1979 MMC investigation concluded that a 'complex monopoly' existed in favour of the petrol companies (there are 15 companies listed in the report). That is to say that "one or more of the companies .... conduct their respective affairs by means of one or more specified practices as in any way to prevent, restrict or distort competition" (MMC, 1979, pp 49) $)^{3}$. The areas of concern were the discriminatory pricing, through the system of rebates, and Selective Price Support. However, in spite of this, the MMC took the view that the actions of the companies in this respect were not against the public interest, and as such should be permitted.

The MMC also took the view that price competition in the petrol market had increased in the years leading up to the report, and as such there was little evidence of monopoly pricing. The MMC made no attempt however, to analyse the profitability of the petrol industry, or the return on capital for any of the leading firms. With the exception of the issues concerning price discrimination, the MMC made no comment on the pricing policies of the firms.

\subsection{Price commission investigations.}

Over the same period however, the four leading firms in the industry (Esso, Shell, BP, Texaco) came under the jurisdiction of the Price Commission, and the 
Counter-Inflation Act (1973), and the Price Commission Act (1979). As such, any price increases by the firms had to be approved by the Price Commission, following an investigation. This took place during the period of rapid oil price increases of 1979 (see figure 1), and as a result, the companies were allowed two successive price rises, early in 1979 , amounting to just under $12 \%$. While there is no evidence that these price rises were designed to increase profitability above the 1978 level, it is clear that such an outcome will have had a positive impact on the profit margins of the companies concerned.

\subsection{Subsequent Investigations and Regulation.}

Partly as a result of the MMC investigation, the Price Marking (petrol) Order came into operation in January 1981. This was a statuary instrument, ordered by the Secretary of State for Trade and Industry. This was introduced to ensure that prices were displayed in gallons as well as litres, as litres were viewed at the time to be misleading. As such, displaying prices in the more 'transparent' pence per gallon, was viewed as facilitating greater competition. This has since been superseded by European regulations, concerning the pricing of goods in metric units.

In addition to general competition policy, the UK petrol industry has also fallen under the scrutiny of the House of Commons Trade and Industry Select Committee. There have been two investigations by this group of MPs into petrol retailing, essentially concerning the prospects for price discrimination within the industry.

The Committee's concerns surrounded price differences over small distances, supported through the Selective Price Support system. The investigation carried out by the House of Commons Trade \& Industry Select Committee (1988a) took the view 
that intra-firm price differences provided evidence of some monopoly pricing in particular locations. They concluded however, that this was an extremely complex issue, and recommended a reference to the MMC. While the powers of the Trade and Industry select committee are somewhat limited in themselves, and as such one would not anticipate a change in conduct of the companies during such an investigation, it is clear from the MMC report, that the select committee were instrumental in bringing about the 1990 MMC referral. Indeed, the select committee were strongly critical of the OFT's failure to bring about a suitable change in conduct, and therefore profitability.

\subsection{The 1990 MMC Investigation}

In contrast with the previous report, the 1990 investigation discusses pricing of petrol at length. The commission found that pump prices follow the Rotterdam spot price, and that there was little reason to assume monopoly profits in the industry. The analysis employed by the MMC however is somewhat simplistic, and several of their conclusions have however been questioned. Bacon (1991) for example demonstrates that petrol price responses to oil price changes are asymmetric.

Despite this evidence of monopoly behaviour, there are several explanations why the commission again came to the conclusion that the conduct of the petrol companies was not against the public interest. Much of the reasoning was based on the increasing market share of supermarkets in petrol retailing, acting to increase competition. However, by 1988 the share of the market controlled by supermarkets, had only increased to $5.5 \%$, while sites directly controlled by wholesalers still accounted for $54 \%$. 


\section{The Impact of Investigations}

Following the above discussion, and the empirical work by Bacon (1992) and Driffield (1999), a two part hypothesis can be formed. Firstly, that petrol companies were able to generate some monopoly rents over at least a part of the period. Secondly, that the investigations, and subsequent regulation had an impact on profit margins. One possibility is that these firms were engaging in monopoly pricing, and amended their conduct as a result of the threat of action by the MMC. This would be particularly pertinent to the 1979 investigation, as there had been significant criticism of the industry following the 1975 oil price shock.

\subsection{The Data ${ }^{4}$}

The data used here are monthly from May 1973 to April 1993. The net petrol price is retail price minus excise duty and VAT, while the oil price is the sterling equivalent price of a gallon of oil. ${ }^{5}$

\subsection{Analysis of the profit margin.}

As the structure of the industry is transparent, with high concentration ratios, many of the investigations outlined above, such as the MMC inquiries, the Price Commission reports, and indeed the 1998 OFT report into the petrol industry, have tended to rely on accounting based measures of performance in order to infer the conduct of the industry. The use for example of return on capital employed to infer industry conduct, is likely to generate misleading conclusions, due to the well-known problems with reliability of accounting measures of profit. 
As can be seen from figure 1, both the retail price of petrol, and the oil price have been somewhat volatile over the time period, and so to focus on whether petrol prices are 'too high', as the Trade and Industry select committee did, for example, would be equally misleading.

Insert figure 1 here. ${ }^{6}$

This paper therefore focuses on a measure of the profit 'margin' that petrol companies generate on a gallon of petrol. This allows explicit evaluation of the impacts of the reports and investigations outlined in section 2. If the companies were generating monopoly rents, then clearly the fundamental role of the many investigators and regulators in this industry, should be to reduce this margin.

Following Driffield (1999), the major determinants of petrol price are oil price, excise duty, and the sterling dollar exchange rate. We therefore calculate a margin for the petrol companies, given by :

$\phi=$ net retail petrol price - oil price (expressed in $£ /$ gallon)

The discussion of the impact of regulation on conduct and performance in the petrol industry, now focuses on this margin. We first present some graphical evidence based on the decomposition of the margin into a flexible trend, which captures fluctuations in low frequencies and cyclical and other high frequency random fluctuations. The Hodrick-Prescott filter, Hodrick et al (1984) allows the data to determine this trend by splitting the series $\{\phi(t)\}_{t=1}^{T}$ into two parts,

$$
\{s(t)\}_{t=1}^{T} \text { and }\{\phi(t)-s(t)\}_{t=1}^{T} \text { in a way that it minimises the following criterion }
$$
function : 
$\left\{(1 / T) \sum_{t=1}^{T}(\phi(t)-s(t))^{2}+(\lambda / T) \sum_{t=2}^{T-1}[(s(t+1)-s(t))-(s(t)-s(t-1))]^{2}\right\}$

where $\lambda>0$ penalises fluctuations of the trend series $\{s(t)\}$

The usual value for this parameter using monthly data is 14400 , larger value of $\lambda$ will result in a smoother trend.

Insert figure 2 here

Figure 2 illustrates the 'raw' margin data, and the smoothed data using the filter. The shaded periods are the times between the announcements of MMC enquiries, and the completion of the report. In both cases, it is clear that the "trend" in petrol margins declined as soon as an enquiry was announced. This therefore tentatively suggests that the petrol companies modified their behaviour once an investigation was announced.

While this provides an interesting illustration of the impact of the MMC on conduct, this is not sufficient to demonstrate that profit margins were abnormally high, as it is necessary to focus on the long run changes in the margin.

\section{Investigations and changes in the petrol margin.}

As noted above, there have been several regulatory measures which have may have impacted on the profitability of the petrol company. The issue here, is not merely whether the judgements of the investigators changed the conduct of the firms, but whether conduct changed beyond the duration of the investigation. As illustrated above, any such shift in industry conduct is likely therefore to persist after the investigation is completed. 
In a general sense, the problem of determining the impact of the investigation, can be defined as follows : suppose a stationary time series is generated by an autoregressive process. Define a 'break' in the series as a shift in the mean value which corresponds to a change in the intercept of the autoregressive process. The question is how does one determine whether such breaks occur and if so where they occur. A subsequent question is to what extent these breaks are long or short lasting.

Consider the regression:

$$
\mathrm{p}(\mathrm{t})=\mathrm{a}_{0}+\mathrm{A}(\mathrm{L}) \mathrm{p}(\mathrm{t}-1)+\mathrm{u}(\mathrm{t})
$$

where $\mathrm{p}(\mathrm{t})$ is the variable of interest, $\mathrm{a}_{0}$ is the constant term $\mathrm{A}(\mathrm{L})$ is a polynomial in the lag operator and $\mathrm{u}(\mathrm{t})$ is a white noise error term. Define the dummy variable $\mathrm{D}(\mathrm{st})=1$ if the date is "on or after date s" (when the event occurs), and zero otherwise.

Conventionally, dummy variables are used to augment the regression

$$
\mathrm{p}(\mathrm{t})=\mathrm{a}_{0}+\mathrm{A}(\mathrm{L}) \mathrm{p}(\mathrm{t}-1)+\mathrm{bsD}(\mathrm{st})+\mathrm{u}(\mathrm{t})
$$

In effect then bs is measuring the magnitude of the hypothesised mean change that occurred in date $\mathrm{s}$.

However when there are several such breaks that may counteract each other the parameter vector bs will not be precisely estimated, and furthermore the secondary question of whether the break persisted into the long term cannot be adequately answered.

To avoid such problems Willard et al. (1996) follow a procedure suggested by Banerjee et al. (1992) which mimics that of Hamilton (1989) although is 
computationally less cumbersome. The procedure estimates by a series of autoregressive processes using a rolling regression (of fixed window) and sequentially tests for the significance of the coefficient of the dummy variable. When the hypothesis is strongly rejected, one is able to identify the period of break, and using the 'latest' estimated parameters estimate the short and long run change in the mean of the series due to the event. By estimating a series of rolling regression this approach implies that both the constant term and the autoregressive parameters also change over time, and in addition the results will be conditioned on the window length.

Here we develop a similar approach that a) takes into account explicitly the possibility of the moving parameters and b) is independent of the arbitrarily chosen window length used in the rolling regressions.

We estimate the autoregressive process by a Kalman filter algorithm, thus the parameters are updated as to produce optimal forecasts, we then use the state vector to test whether its observed variability can be accounted by the presupposed events. Having taken into account the coefficient's inertia we are then able to estimate the persistence of the break on the intercept.

This analysis involves the use of a Kalman filter to analyse the movements in our margin.

\subsection{Kalman Filter Analysis.}

State-space form 
Following Hamilton (1994) the vector of the observed variables at time t, $\phi_{t}$, is related to the vector of betas, known as the 'state vector', via the measurement equation.

$$
\phi_{\mathrm{t}}=\mathrm{I}_{\mathrm{t}}+\vartheta_{\mathrm{t}} * \phi_{\mathrm{t}-1}+\mathrm{M}_{\mathrm{t}}
$$

where $E\left(M_{t}\right)=0$ and $\operatorname{var}\left(M_{t}\right)=H_{t}$

The elements of the state vector are generally not observable but they are assumed to follow a first-order Markov process. This is incorporated in the transition equation.

$$
\vartheta_{\mathrm{t}}=\mathrm{T}_{\mathrm{t}} * \vartheta_{\mathrm{t}-1}+\mathrm{O}_{\mathrm{t}}
$$

where $T_{t}$ is a square matrix

$$
\mathrm{E}\left(\mathrm{O}_{\mathrm{t}}\right)=0 \text { and } \operatorname{var}\left(\mathrm{O}_{\mathrm{t}}\right)=\mathrm{Q}_{\mathrm{t}}
$$

To complete the specification of the state-space system two further assumptions are made.

- the initial state vector has a mean of $\mathrm{b}_{0}$ and a covariance matrix of $\mathrm{P}_{\mathrm{o}}$ thus $\vartheta_{0} \sim \mathrm{N}\left(\mathrm{b}_{0}, \mathrm{P}_{\mathrm{o}}\right)$

- the disturbances $\mathrm{O}_{\mathrm{t}}$ and $\mathrm{M}_{\mathrm{t}}$ are uncorrelated with each other across all time periods, and uncorrelated with the initial state

$$
\mathrm{E}\left(\mathrm{M}_{\mathrm{t}}, \mathrm{O}_{\mathrm{t}}\right)=0 \quad \mathrm{E}\left(\mathrm{M}_{\mathrm{t}}, \mathrm{b}_{0}\right)=0 \quad \mathrm{E}\left(\mathrm{O}_{\mathrm{t}}, \mathrm{b}_{0}\right)=0
$$

The matrices in the measurement and in the transition equations are assumed to be nonstochastic. Although they may change with time, these variations are predetermined. If we fix $\mathrm{T}_{\mathrm{t}}$ over time, the transition equation becomes a first-order autoregressive process. Hence, the parameter beta is not constrained to having a fixed 
mean but is allowed to vary over time. These variations are determined by the statistic $Q_{\mathrm{t}}$

Once the model has been formulated in state-space form, various algorithms may be applied. The main one is the Kalman filter which is a recursive procedure for calculating the optimal estimator of the state vector given, all of the information which is currently obtainable. A backward recursion, known as smoothing, is also available. It enables optimal estimation of the state vector's components to be calculated at all points in time, using the full sample of information accessible. Given the information on the dependent variable, $\phi_{\mathrm{t}}$, Kalman filter recursions are applied in three distinct stages. First, from the initial estimate of beta at time $t-1, b_{t-1}$, and its covariance matrix $\mathrm{P}_{\mathrm{t}-1}$ prediction equations are derived that will provide the optimal estimator of the state vector $\vartheta_{t}$ by minimum mean square linear estimation. The prediction equations are :

$$
\begin{aligned}
& \mathrm{b}_{\mathrm{t} / \mathrm{t}-1}=\mathrm{b}_{\mathrm{t}-1} \\
& \mathrm{p}_{\mathrm{t} / \mathrm{t}-1}=\mathrm{p}_{\mathrm{t}-1}+\mathrm{Q}_{\mathrm{t}}
\end{aligned}
$$

The corresponding estimator of the dependent variable is :

$$
\phi_{\mathrm{t} / \mathrm{t}-1}=\phi_{\mathrm{t}-1} * \mathrm{~b}_{\mathrm{t} / \mathrm{t}-1}
$$

Thus, the error made in predicting the minimum mean square linear estimation at time $\mathrm{t}-1$ is :

$$
\begin{aligned}
\mathrm{Y}_{\mathrm{t}} & =\phi_{\mathrm{t}}-\phi_{\mathrm{t} / \mathrm{t}-1} \\
& =\phi_{\mathrm{t}-1} *\left(\vartheta_{\mathrm{t}}-\mathrm{b}_{\mathrm{t} / \mathrm{t}-1}\right)+\mathrm{M}_{\mathrm{t}}
\end{aligned}
$$


In a second stage the estimator of the state vector can be updated once additional information becomes available. The corresponding updating equation is :

$$
\mathrm{b}_{\mathrm{t}}=\frac{\mathrm{b}_{\mathrm{t} / \mathrm{t}-1}+\mathrm{P}_{\mathrm{t} / \mathrm{t}-1} *\left[\phi_{\mathrm{t}-1}\right]_{\mathrm{t}}}{[\phi]_{\mathrm{t}-1} * \mathrm{P}_{\mathrm{t} / \mathrm{t}-1} *\left[\phi_{\mathrm{t}-1}\right]+\mathrm{H}_{\mathrm{t}}}
$$

where $\mathrm{H}_{\mathrm{t}}$ is the covariance matrix of the error term of the measurement equation.

The gain from the Kalman procedure is :

$$
\frac{\mathrm{P}_{\mathrm{t} / \mathrm{t}-1} *[\phi]_{\mathrm{t}-1}}{\phi_{\mathrm{t}-1} * \mathrm{P}_{\mathrm{t} / \mathrm{t}-1} * \phi_{\mathrm{t}-1} * \mathrm{H}_{\mathrm{t}}}
$$

The prediction error plays a key role in the updating. The more the predictor of observation deviates from its realisation, the bigger the change made to the estimator of the state vector.

Finally, smoothing equations are initiated to essentially reverse the filtering process. The fixed-interval smoothing algorithm consists of a set of recursions which start with the final quantities, $\mathrm{b}_{\mathrm{T}}$ and $\mathrm{P}_{\mathrm{T}}$, given the Kalman filter and work backwards. The smoothing equations are :

$$
\begin{aligned}
& b_{t / T}=b_{t}+P^{\prime}{ }_{t} *\left(b_{t+1 / T}-b_{t}\right) \\
& P_{t / T}=P_{t}+P^{\prime}{ }_{t} *\left(P_{t+1 / T}-P_{t+1 / t}\right) * P^{\prime}
\end{aligned}
$$

where $\mathrm{P}_{\mathrm{t}}=\mathrm{P}_{\mathrm{t}} * \mathrm{P}^{-1}{ }_{\mathrm{t}+1 / \mathrm{t}}$ $\mathrm{t}=\mathrm{T}-1, \mathrm{~T}-2, \ldots . ., 1$ 
In the end the Kalman filter will provide an estimated value adjustment coefficient for each time period. The resulting series can subsequently be used to test the beta parameter's stationarity.

The essential advantage of this process, is that it allows for the continual updating of parameters as more information becomes available. Slade (1989) for example demonstrates the gain from this procedure in modelling price wars. In the case presented here however, rather than the companies updating their information on the demand equation, they are effectively updating their supply behaviour based on anticipated regulatory action. The use of the Kalman filter therefore allows for the presence of an autoregressive process in the parameters. This therefore allows the impact of any change due to regulation to be carried beyond the period of regulation. Thus, if there is an exogenous factor which acts to change the margin, the influence of this factor will continue beyond the period of the shock.

The process here uses an expression for the margin, $\phi_{\mathrm{t}}$ :

$$
\phi_{\mathrm{t}}=\alpha_{\mathrm{t}}+\beta_{1 \mathrm{t}}^{*} \phi_{\mathrm{t}-1}+\beta_{2 \mathrm{t}}^{*} \phi_{\mathrm{t}-2}+\mathrm{u}_{\mathrm{t}}
$$

The Kalman filter is applied to this, to extract $\alpha$, which is the 'long run' margin. This however is not merely a fixed coefficient, as the Kalman filter technique continually updates it given new information. It is then possible to test the extent to which exogenous influences impact on this long run margin.

Thus, the final expression which is used to evaluate the long run impact of investigation or regulation is :

$$
\hat{\alpha}_{\mathrm{t}}=\mathrm{c}+\mathrm{c}_{1} * \hat{\alpha}_{\mathrm{t}-1}+\sum_{\mathrm{j}=2}^{7} \mathrm{c}_{\mathrm{j}}^{*} \mathrm{D}_{\mathrm{j}-1}+\varepsilon_{\mathrm{t}}
$$


where $\mathrm{D}$ is the set of dummy intervention variables given above.

The possible causes of changes in the margin are as follows :

$D_{1}=1$ for the duration of the 1979 MMC report.

$\mathrm{D}_{2}=1$ for the duration between the publication of the report and any decision made by the Secretary of State.

$\mathrm{D}_{3}, \mathrm{D}_{4}$ as above for the 1990 report.

$\mathrm{D}_{5}$ the duration of the Trade \& Industry Select Committee investigation.

$\mathrm{D}_{6}=1$ for the duration of the imposition of the Petrol Price Marking Order.

Given the very nature of $\hat{\alpha}_{t}$ variable, this a very rigorous test of the long run impact of intervention. The results from the estimation of equation (13) by OLS are given in table 1 : 


\section{Results}

table 1 here

The results here show clearly that the instigation of the 1979 MMC inquiry had a significant negative effect on the margins of the petrol companies. This result would appear to contradict the MMC, that the petrol companies were not generating monopoly profits, as the companies responded to the announcement of the investigation by reducing their margins. All other investigations, or attempts at regulation, such as the Marking Order, have been ineffective at reducing profitability. The instigation of the second report did not have similar effect on profitability. This is the expected result. The MMC had already given the industry a favourable verdict in 1979 , so the industry had little treason to suppose that its conduct would be found to be against the public interest the second time.

As this paper demonstrates, the 1979 investigation therefore changed the conduct of the oil companies in the long term, such that margins were reduced. As such therefore, given the previous findings of the MMC, there was little reason for the companies to anticipate an adverse finding eleven years on. Finally, concerning the deliberations of the MMC in general, Clarke et al. (1998) report that the likelihood of an industry being found to be not acting against the public interest has significantly increased since 1979. In addition, there is significant evidence that firms involved in more than one investigation learn a good deal from the experience in terms of how to put their case to the commission, and in subsequent investigations hire specialists, and employ much higher levels of resources in producing their submissions than the first time, thus increasing their chance of 'success'. 


\section{Conclusions.}

This paper demonstrates that the regulatory bodies in the UK inadvertently had a significant effect on consumption efficiency within the petrol industry. This is despite the fact that the industry has never been found to be acting against the public interest.

There are many reasons to believe that this industry may behave as a collusive oligopoly, and there is significant evidence of restrictive practices in the industry. Intra-brand competition is all but negated by the petrol companies, and horizontal restrictions act to severely limit inter-brand competition. While it is impossible to prove monopoly pricing on the part of the petrol companies, certain conclusions can be inferred. The threat of an adverse report, or government regulation of the petrol industry, was sufficient to change the conduct of the companies. This had the effect of reducing profit margins from 1977 onwards. There is also evidence that this effect persisted after the publication of the report. Finally, there is no evidence that any subsequent investigations have been as effective. 
Appendix : Unit root tests on the profit margin.

Unit root tests: Phillips - Perron test statistics.

\begin{tabular}{|l|l|l|l|l|l|}
\hline No of lags & 0 & 1 & 2 & 3 & 4 \\
\hline Test Stat. & -23.98 & -25.96 & -26.25 & -26.92 & -26.95 \\
\hline P-value & 0.03 & 0.02 & 0.02 & 0.02 & 0.02 \\
\hline
\end{tabular}


Table 1 : Determinants of the gross margin.

Dependent variable : $\hat{\alpha}_{\mathrm{t}}$

Estimated

$\begin{array}{llll}\text { Variable } & \text { Coefficient } & \text { t-statistic } & \text { P-value } \\ \text { constant } & 0.528 & 6.42^{* *} & {[0.000]} \\ \hat{\alpha}_{\mathrm{t}-1} & 0.676 & 14.22^{* *} & {[0.000]} \\ \mathrm{D}_{1} & -0.137 & -2.23^{* *} & {[0.026]} \\ \mathrm{D}_{2} & -0.058 & -0.62 & {[0.539]} \\ \mathrm{D}_{3} & -0.102 & -1.19 & {[0.236]} \\ \mathrm{D}_{4} & 0.097 & 0.98 & {[0.326]} \\ \mathrm{D}_{5} & -0.029 & -0.22 & {[0.827]} \\ \mathrm{D}_{6} & 0.099 & 0.81 & {[0.418]}\end{array}$

** significant at the $95 \%$ level.

Mean of dependent variable $=1.603$

Std. dev. of dependent var. $=0.4708$

Sum of squared residuals $=22.76$

Variance of residuals $=0.099$

Std. error of regression $=0.3139$

R-squared $=0.568$

Adjusted R-squared $=0.556$

Durbin's $h=0.096[p=0.923]$

Durbin's h alternative $=0.288[\mathrm{p}=0.773]$

Breusch/Godfrey LM: AR/MA1 $=0.0831[\mathrm{p}=0.773]$ 
Figure 1.

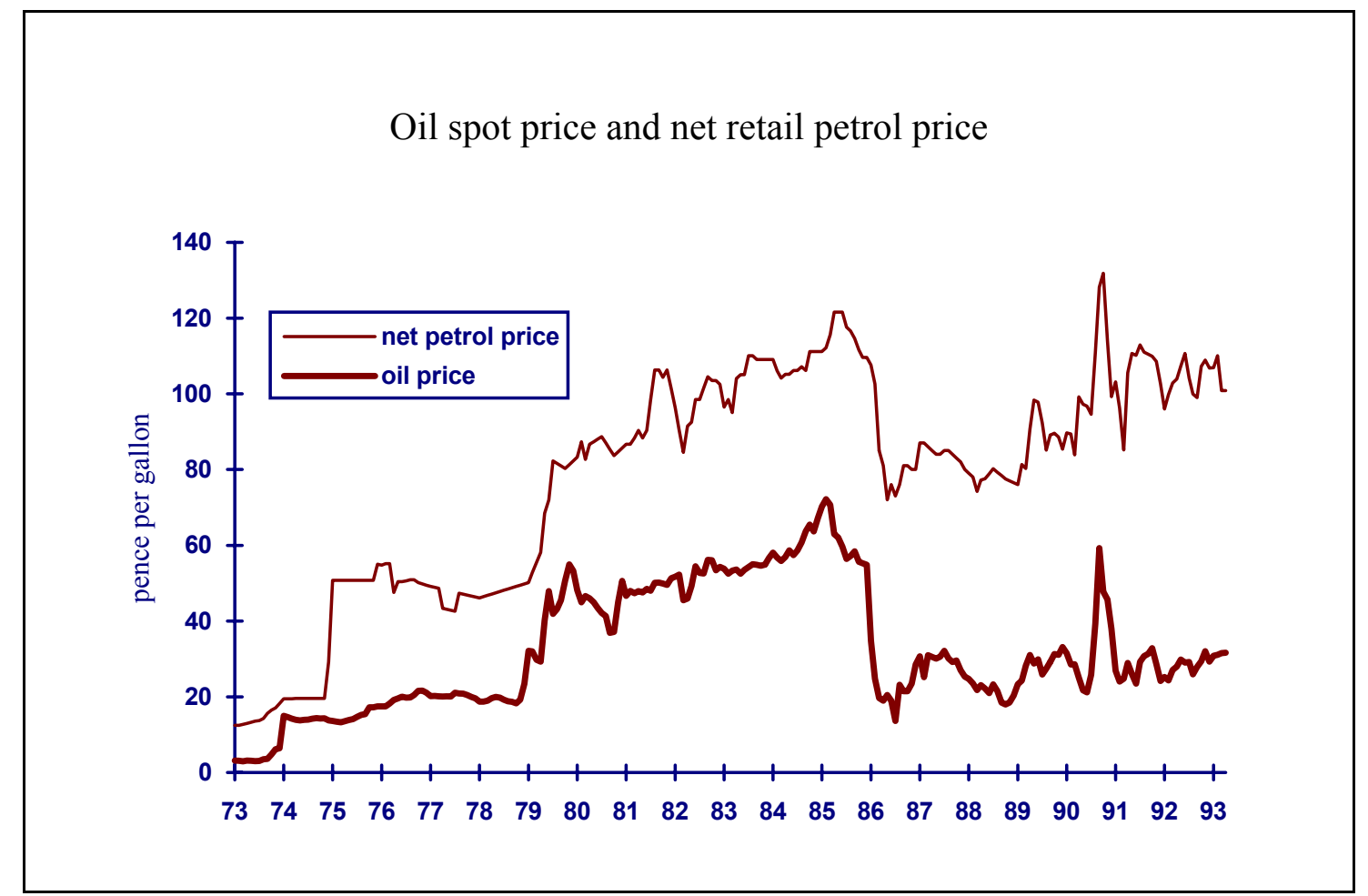


Figure 2.

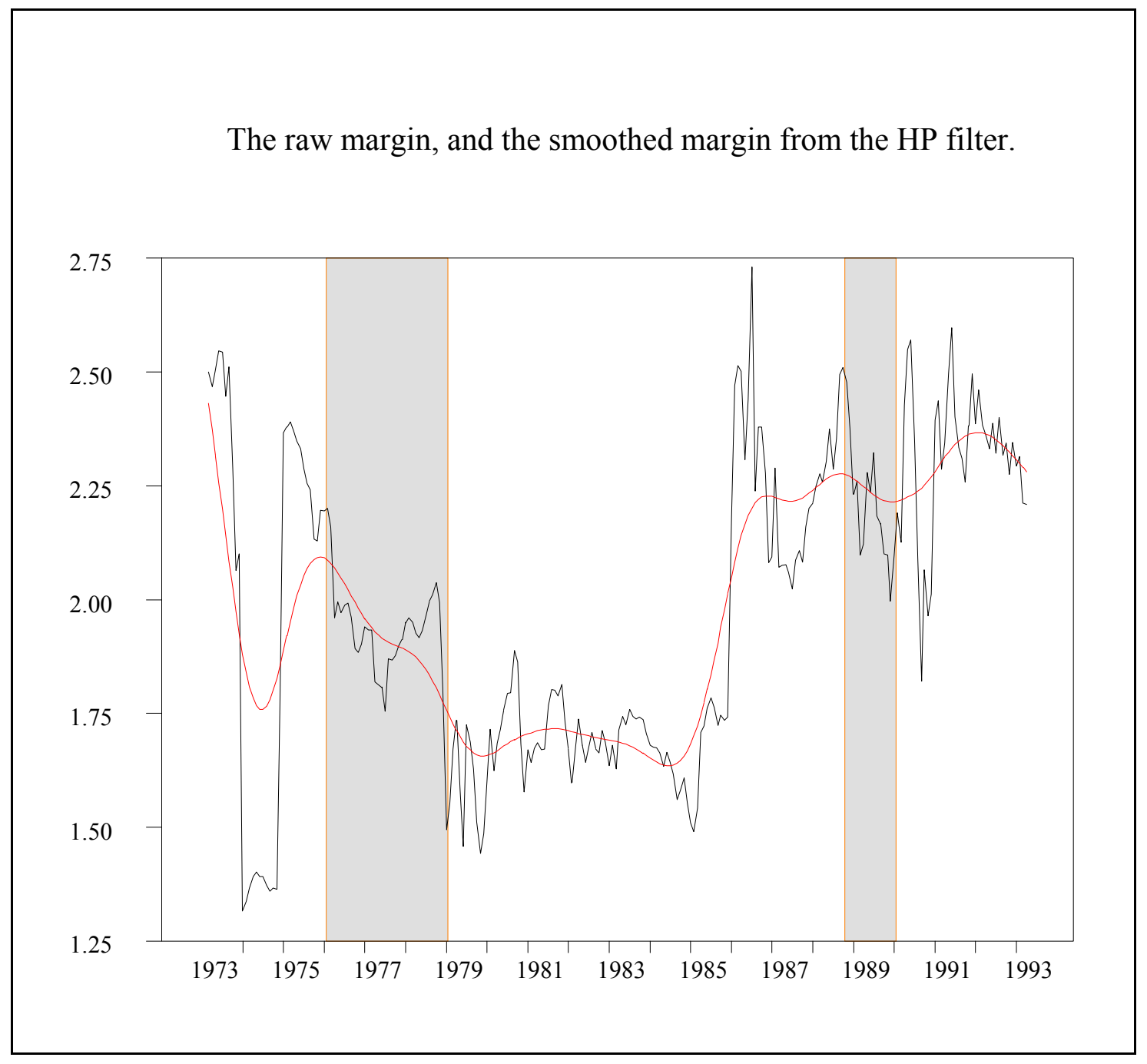




\section{References}

Bacon, R.W. (1991) 'Rockets and feathers: the asymmetric speed of adjustment of UK retail gasoline prices to cost changes.' Energy Economics, 13 (3) pp. 211- 218.

Banerjee A, Lumsdaine R.L. \& Stock J.H. (1992) 'Recursive and Sequential tests on the unit root and trend break hypothesis: Theory and international evidence' Journal of Business and Economic statistics, 10 (3) pp 271-87

Borenstein, S., Cameron, A.C. \& Gilbert, R. (1997) 'Do gasoline prices respond asymmetrically to crude oil price changes?' Quarterly Journal of Economics, 112 (1) pp 305-339.

Borenstein, S. \& Shepard, A. (1996) 'Dynamic pricing in retail gasoline markets.' Rand Journal of Economics, 27 (3) pp. 429-51.

Bork, R. (1978) The Anti-trust paradox. Basic Books, New York.

Clarke, R, Davies, S.W. \& Driffield, N.L. (1998) Appraising monopoly policy: Evidence from the UK. Edward Elgar.

Dobson, P.W. \& Waterson, M. (1996) Vertical Restraints and competition policy, OFT Research Papers, no. 12.

Driffield, N.L. (1999) 'Regulation of the petrol Industry : Issues \& Evidence.' International Journal of the Economics of Business, forthcoming.

Gilligan, T.W. (1986) The competitive effects of retail price maintenance. Rand Journal of Economics, 17 (4) pp. 544-56.

Hodrick R.J. and Prescott E.C. (1984) 'Post-War US Business Cycles: An Empirical Investigation' working paper, Carnegie Mellon University, PittsburghHamilton J D (1989) 'A new approach to the Economic Analysis of nonstationary time series and the business cycles' Econometrica 57 (2) pp 357-84.

Hamilton J.D (1994) : Time Series Analysis Princeton University Press.

House of Commons: 
The Energy Committee :The Price Marking (Petrol) Order 1980. Statutory Instruments 1980 no 1121.

Trade and Industry Select Committee (1988a) Second Report: Petrol retailing in the UK.

Trade and Industry Select Committee (1988b) Third Report: Petrol retailing in the UK.

Lin, Y.J. (1990) 'The dampening-of-competition effect of exclusive dealing.' The Journal of Industrial Economics, 39 (2) pp. 209-223.

The Monopolies and Mergers Commission (1979) Petrol : A report on the supply of petrol by wholesale. HMSO.

The Monopolies and Mergers Commission (1990) The Supply of Petrol : A report on the supply in the United Kingdom of petrol by wholesale. HMSO.

O’Brien, D.P. \& Shaffer, G. (1992) 'Vertical control with bilateral contracts.' Rand Journal of Economics, 23 (3) pp. 299-308.

Phillips, P.C.B. \& Perron, P. (1988) 'Testing for a unit root in time series regressions.' Biometrika, 75 pp. 335-346.

Posner, R. (1981) 'The next step in the antitrust treatment of restricted distribution per se legality.' University of Chicago Law Review, 48 pp. 6-26.

Slade, M.E. (1990) Strategic pricing models and interpretation of price - war data. European Economic Review no 34 pp 524-37.

Slade, M.E. (1989) Price wars in price setting supergames. Economica, 56 pp 295310.

Slade, M.E. (1992) Vancouver's gasoline-price wars: An empirical exercise in uncovering supergame strategies. Review of Economic Studies no 59 pp 257-76.

Slade, M.E. (1993) Strategic moves for vertical separation : Evidence from retail gasoline. University of British Columbia Mimeo. 
Vickers, J. \& Waterson, M. (1991) 'Vertical relationships - An introduction.' Journal of Industrial Economics, 39 (5) pp. 445-450.

Willard K.L. Cuinnane T.W. Rosen H.S. (1996) 'Turning points in the Civil War : Views from the Greenback Market' American Economic Review, 86 (4) pp 1001-1018

${ }^{1}$ Competition in the supply of petrol in the UK, Office of Fair Trading, May 1998.

${ }^{2}$ Referral is generally made on the basis of market shares, predatory pricing, collusive behaviour, or vertical restraints. This process is described at length in Clarke et al (1998), although at the time of writing, there are various changes anticipated, following publication of the 1997 Competition Bill, which will serve to give the OFT further powers.

${ }^{3}$ A complex monopoly is deemed to exist where more than one firm, engaged in the same conduct ( in this case vertical restraints) have a total market share of greater than $25 \%$. This is opposed to a scale monopoly, where at least one firm has a market share of greater than $25 \%$.

${ }^{4}$ With the exception of the petrol price data, and the excise duty, which are taken from the Digest of UK Energy Statistics, and the Herfindahl index, which is taken from the MMC 1990 report all the data can be extracted from Datastream.

${ }^{5}$ Clearly, a given barrel of oil will be used to manufacture many products besides petrol. However, as we demonstrate subsequently, the only necessary assumption here is the the fraction of a unit Saudi Light oil which is distilled to petrol is time invariant. There is no technological reason to contradict this.

${ }^{6}$ coefficient of variation in oil spot price in sterling $=0.511$

coefficient of variation in petrol retail price 0.379

correlation coefficient between oil and petrol prices : 0.773 